\title{
Editorial for Special Issue "Petrology, Geochemistry and Mineralogy of the Mantle as Tools to Read Messages from the Earth's Interior"
}

\author{
Shoji Arai $\odot$ \\ Department of Earth Sciences, Kanazawa University, Kanazawa 920-1192, Japan; ultrasa@staff.kanazawa-u.ac.jp \\ Received: 28 February 2019; Accepted: 1 March 2019; Published: 2 March 2019 \\ check for \\ updates
}

This Special Issue contains nine articles [1-9]. Seven of them [1-6,8] deal with mantle-derived rocks, which have played an essential and important role in providing us with direct information about the chemistry and processes that take place in the deep part of Earth [10,11]. Their geochemistry and mineralogy give us excellent tools to unravel various mantle processes, i.e., partial melting, melt extraction, melt-rock interaction, metallogeny, metasomatism and metamorphism. Five papers $[1,3,4,6,8]$ describe and discuss mantle-derived peridotites from Asia. Interesting new data are presented regarding the origin of mantle wedges and the nature of ophiolites [1,3,4,6]. Readers will be interested in the relationship between abyssal peridotites and arc peridotites. Two papers $[2,5]$ refer to so-called "UHP (ultra-high pressure) chromitites", the origin of which has been highly controversial [12-14]. Those authors try new approaches to the origin of the "UHP chromitite" for our understanding of them. Erupted basic magmas also give us clues to mantle conditions and processes related to magma production [15-18]. One paper [7] is devoted to the understanding of mantle processes during continent breakup using the information from mafic intrusions. The Earth's interior below the mantle is always a subject of great interest, although it is usually beyond the reach of ordinary petrological methods $[19,20]$. One paper [9] deals with the deformation character of wadsleyite and ringwoodite, which are high-pressure polymorphs of olivine.

Arai et al. [1] describe peridotite xenoliths from a new locality (Bankawa), which is located in forearc area of the Southwest Japan arc, and discuss the petrologic nature of the mantle wedge. The Bankawa peridotite xenolith suite is composed of almost uniform lherzolite, which is similar to some abyssal lherzolites. The authors present a model of the mantle wedge; the mid-ocean ridge peridotite variously modified by partial melting, reaction and metasomatism above a subducting slab. Japanese readers may be especially interested in the result because the Bankawa locality was recently found and this paper presents a new dataset for mantle peridotite beneath the Japan arcs.

Miura et al. [2] deal with chromitites from the Higashi-akaishi peridotite complex in the high-pressure-type Sanbagawa metamorphic belt, Japan in order to understand the nature of UHP (ultrahigh-pressure) chromitites. UHP chromitites have been so far designated not by their P-T condition but only by the presence of UHP minerals such as coesite and diamond [21]. This paper is quite unique in that the chromitites have experienced UHP conditions because they are coherently enclosed by the UHP Higashi-akaishi peridotite of garnet-peridotite facies. The authors show that Higashi-akaishi chromitites share a petrographic feature, i.e., pyroxene lamellae in chromite, with reported UHP chromitites [22], although no UHP minerals were detected.

Payot et al. [3] report an occurrence of lherzolite in the Pinatubo peridotite xenolith suite, which is dominated by spinel harzburgites [23]. Depleted spinel harzburgites of island arc affinity are predominant in other xenolith suites from the Philippines [24]. The authors show that the lherzolite is very similar in mineral chemistry to an abyssal lherzolite. This possibly means that part of the mantle wedge beneath Luzon Island is composed of abyssal peridotites. This result is consistent 
with that of Arai et al. [1] and also contributes to our better understanding of mantle wedges and island-arc systems.

Ishimaru et al. [4] describe the petrological characteristics of a deep section (Moho transition zone to the upper mantle) of the Mersin ophiolite, Turkey, which contains upper crustal rocks of island-arc affinity. They consider the Mersin ophiolite as one of the island-arc-type end-member ophiolites in terms of the properties of crustal rocks. The authors recognize that all of the deep-seated rocks show an island-arc character in terms of mineral chemistry. It is noted that the Moho-transition zone (MTZ) dunite is more depleted that the mantle harzburgite in Mersin in terms of spinel chemistry. The depleted MTZ dunite is a product of peridotite-magma reaction and in equilibrium with the boninitic magma. This work is successful in that it succeeded in locating boninite magma production in the MTZ for the first time. This is consistent with the recent result on boninite genesis from erupted boninitic magmas $[25,26]$.

Pujol-Solà et al. [5] examined ophiolitic chromitites from Cuba and found apparently "exotic" minerals that show a "super-reduced" condition, such as moissanite and alloys. The authors ascribe their origin to secondary reduced microenvironments during low-temperature serpentinization. These minerals are characteristic of some UHP chromitites, and the authors propose a new idea of the origin of UHP chromitites as recycled rocks that had experienced serpentinization.

Morishita et al. [6] examined peridotites from the Andaman ophiolite. Origins of ophiolites and ophiolitic peridotites have been always a matter of debate $[27,28]$. The authors highlight the mid-ocean ridge nature of the lherzolitic mantle peridotite of that ophiolite by using petrologic and isotopic characteristics. The relevance of the origin of the Andaman ophiolite to the evolution of the Indian Ocean is interesting.

Shu et al. [7] report two diabase intrusions of the Proterozoic exposed in a western part of the Yangtze Block, China. One shows an affinity to intraplate magma while the other is of island-arc affinity, although they show almost the same age (ca. $780 \mathrm{Ma}$ ). This may record an intraplate mantle upwelling during breakup of the Rodinia supercontinent and the preceding mantle-wedge magmatism during continental accretion.

Ejima et al. [8] examined the redox state of the upper mantle using the ferric iron content of olivine in mantle-derived peridotite xenoliths from a rift zone in Mongolia. This method is different from the conventional oxygen barometer based on olivine-orthopyroxene-spinel equilibrium [29]. The $\mathrm{Fe}^{3+} /$ total Fe ratio is about 0.027 in the olivine of $\mathrm{Fo}_{89.9}$. The oxygen barometer of Ballhaus et al. [29] yields $\Delta \log \left(f \mathrm{O}_{2}\right) \mathrm{FMQ}\left(f \mathrm{O}_{2}\right.$ relative to the $\mathrm{FMQ}$ buffer $)=3.4-3.6$, which is higher than the average value of mantle peridotites reported so far (usually $<1$ ) [30]. The $\mathrm{Fe}^{3+}$ content of mantle silicates, especially olivine, is potentially a proxy of the mantle redox condition.

Nyogang et al. [9] observe synthetic aggregates of wadsleyite and ringwoodite, high-pressure olivine polymorphs, by TEM. The authors calculate local misorientations and misorientation gradients, and suggest almost the same plastic strain character between the two minerals at $17.3 \mathrm{GPa}$ and $1700 \mathrm{~K}$.

\section{References}

1. Arai, S.; Tamura, A.; Miura, M.; Seike, K. Abyssal peridotite as a component of forearc mantle: Inference from a new mantle xenolith suite of Bankawa in the Southwest Japan arc. Minerals 2018, 8, 540. [CrossRef]

2. Miura, M.; Arai, S.; Mizukami, T.; Shmelev, V.R.; Ishimaru, S. Petrology of chromitites in the Higashi-akaishi ultrahigh-pressure (UHP) peridotite complex, Japan: Toward understanding of general features of the UHP chromitites. Minerals 2018, 8, 525. [CrossRef]

3. Payot, B.D.; Arai, S.; Yoshikawa, M.; Tamura, A.; Okuno, M.; Rivera, D.J.F. Mantle evolution from ocean to arc: The record in spinel peridotite xenoliths in Mt. Pinatubo, Philippines. Minerals 2018, 8, 515. [CrossRef]

4. Ishimaru, S.; Saikawa, Y.; Miura, M.; Parlak, O.; Arai, S. Decoding of mantle processes in the Mersin ophiolite, Turkey, of end-member arc type: Location of the boninite magma generation. Minerals 2018, 8, 464. [CrossRef] 
5. Pujol-Solà, N.; Proenza, J.A.; Garcia-Casco, A.; González-Jiménez, J.M.; Andreazini, A.; Melgarejo, J.C.; Gervilla, F. An alternative scenario on the origin of ultra-high pressure (UHP) and super-reduced (SuR) minerals in ophiolitic chromitites: A case study from the Mercedita deposit (eastern Cuba). Minerals 2018, 8, 433. [CrossRef]

6. Morishita, T.; Yoshikawa, M.; Tamura, A.; Guotana, J.M.; Ghosh, B. Petrology of peridotites and Nd-Sr isotopic composition of their clinopyroxenes from the middle Andaman ophiolite, India. Minerals 2018, 8 , 410. [CrossRef]

7. Shu, S.; Yang, X.; Liu, L.; Cao, J.; Gao, E. Dual geochemical characteristics for the basic intrusions in the Yangtze Block, South China: New evidence for the breakup of Rodinia. Minerals 2018, 8, 228. [CrossRef]

8. Ejima, T.; Osanai, Y.; Akasaka, M.; Adachi, T.; Nakano, N.; Kon, Y.; Ohfuji, H.; Sereenen, J. Oxidation states of Fe in constituent minerals of a spinel lherzolite xenolith from the Tariat Depression, Mongolia: The significance of $\mathrm{Fe}^{3+}$ in olivine. Minerals 2018, 8, 204. [CrossRef]

9. Nzogang, B.C.; Thilliez, S.; Mussi, A.; Kawazoe, T.; Miyajima, N.; Bouquerel, J.; Cordier, P. Application of scanning precession electron diffraction in the transition electron microscope to the characterization of deformation in wadsleyite and ringwoodite. Minerals 2018, 8, 153. [CrossRef]

10. Dick, H.J.B.; Bullen, T. Chromian spinel as a petrogenetic indicator in abyssal and alpine type peridotites and spatially associated lavas. Contrib. Mineral. Petrol. 1984, 86, 54-76. [CrossRef]

11. Arai, S. Characterization of spinel peridotites by olivine-spinel compositional relationships: Review and interpretation. Chem. Geol. 1994, 113, 191-204. [CrossRef]

12. Robinson, P.T.; Bai, W.-J.; Malpas, J.; Yang, J.-S.; Zhou, M.F.; Fang, Q.S.; Hu, X.-F.; Cameron, S.; Staudigel, H. Ultra-high pressure minerals in the Luobusa Ophiolite, Tibet, and their tectonic implications. Geol. Soc. Lond. Spec. Pub. 2004, 226, 247-271. [CrossRef]

13. Arai, S. Conversion of low-pressure chromitites to ultrahigh-pressure chromitites by deep recycling: A good inference. Earth Planet. Sci. Lett. 2013, 379, 81-87. [CrossRef]

14. Ballhaus, C.; Wirth, R.; Fonseca, R.O.C.; Blanchard, H.; Pröll, W.; Bragagni, A.; Nagel, T.; Schreiber, A.; Dittrich, S.; Thome, V.; et al. Ultra-high pressure and ultra-reduced minerals in ophiolites may form by lightning strikes. Geochem. Prespec. Lett. 2017, 5, 42-46. [CrossRef]

15. Kelemem, P.B.; Johnson, K.T.M.; Kinzler, R.J.; Irving, A.J. High-field-strength element depletions in arc basalts due to mantle-magma interaction. Nature 1990, 345, 521-524. [CrossRef]

16. Arai, S. Chemistry of chromian spinel in volcanic rocks as a potential guide to magma chemistry. Mineral. Mag. 1992, 56, 173-184. [CrossRef]

17. Arai, S. Compositional variation of olivine-chromian spinel in Mg-rich magmas as a guide to their residual spinel peridotites. J. Volcanol. Geotherm. Res. 1994, 59, 279-293. [CrossRef]

18. Kamenetsky, V.S.; Crawford, A.J.; Meffre, S. Factors controlling chemistry of magmatic spinel: An empirical study of associated olivine, Cr-spinel and melt inclusions from primitive rocks. J. Petrol. 2001, 42, 655-671. [CrossRef]

19. Ringwood, A.E.; Irifune, T. Nature of the 650-km seismic discontinuity-Implications for mantle dynamics and differentiation. Nature 1988, 331, 131-136. [CrossRef]

20. Stachel, T.; Harris, J.W.; Brey, G.P.; Joswig, W. Kakan diamonds (Guinea) II: lower mantle inclusion parageneses. Contrib. Mineral. Petrol. 2000, 140, 16-27. [CrossRef]

21. Yang, J.-S.; Dobrzhinetskaya, L.; Bai, W.-J.; Fang, Q.-S.; Robinson, P.T.; Zhang, J.; Green, H.W., II. Diamondand coesite-bearing chromitites from the Luobusa ophiolite, Tibet. Geology 2007, 35, 875-878. [CrossRef]

22. Yamamoto, S.; Komiya, T.; Hirose, K.; Maruyama, S. Coesite and clinopyroxene exsolution lamellae in chromites: In-situ ultrahigh-pressure evidence from podiform chromitites in the Luobusa ophiolite, southern Tibet. Lithos 2009, 109, 314-322. [CrossRef]

23. Yoshikawa, M.; Tamura, A.; Arai, S.; Kawamoto, T.; Payot, B.D.; Rivera, D.J.; Bariso, E.B.; Mirabueno, M.H.T.; Okuno, M.; Kobayashi, T. Aqueous fluids and sedimentary melts as agents for mantle wedge metasomatism, as inferred from peridotite xenoliths at Pinatubo and Iraya volcanoes, Luzon arc, Philippines. Lithos 2016, 262, 355-368. [CrossRef]

24. Arai, S.; Takada, S.; Michibayashi, K.; Kida, M. Petrology of peridotite xenoliths from Iraya Volcano, Philippines, and its implication for dynamic mantle-wedge processes. J. Petrol. 2004, 45, 369-389. [CrossRef]

25. Umino, S.; Kanayama, K.; Kitamura, K.; Tamura, A.; Ishizuka, O.; Senda, R.; Arai, S. Did boninite originate from the heterogeneous mantle with recycled ancient slab? Island Arc 2017, e12221. [CrossRef] 
26. Perez, A.; Umino, S.; Yumul, G.P., Jr.; Ishizuka, O. Boninite and boninite-series volcanics in northern Zambales ophiolite: Doubly vergent subduction initiation along Philippine Sea plate margins. Solid Earth 2018, 9, 713-733. [CrossRef]

27. Miyashiro, A. The Troodos ophiolitic complex was probably formed in an island arc. Earth Planet. Sci. Lett. 1973, 19, 218-224. [CrossRef]

28. Arai, S.; Kadoshima, K.; Morishita, T. Widespread arc-related melting in the mantle section of the northern Oman ophiolite as inferred from detrital chromian spinels. J. Geol. Soc. 2006, 163, 869-879. [CrossRef]

29. Ballhaus, C.; Berry, R.F.; Green, D.H. High pressure experimental calibration of the olivine-orthopyroxene-spinel oxygen geobarometer: Implications for the oxidation state of the upper mantle. Contrib. Mineral. Petrol. 1991, 107, 27-40. [CrossRef]

30. Arai, S.; Ishimaru, S. Insights into petrological characteristics of the lithosphere of mantle wedge beneath arcs through peridotite xenoliths: A review. J. Petrol. 2007, 49, 665-695. [CrossRef]

C 2019 by the author. Licensee MDPI, Basel, Switzerland. This article is an open access article distributed under the terms and conditions of the Creative Commons Attribution (CC BY) license (http:/ / creativecommons.org/licenses/by/4.0/). 